\title{
SOIL WEED SEED BANK STATUS IN THE AGROECOLOGICAL CONDITION OF CHITRAL, PAKISTAN
}

\author{
Luqman $^{1} *$, Zahid Hussain ${ }^{2}$, Tamana Bakht ${ }^{3}$, Miftah-Ud-Din ${ }^{1}$, Haroon Khan ${ }^{2}$, Muhammad \\ Rameez Khan ${ }^{1}$, Ata Ullah ${ }^{1}$ and Faraz Ali Shah ${ }^{1}$, Imtiaz Khan ${ }^{2}$ and Abdul Majid Khan Dawar ${ }^{2}$
}

\begin{abstract}
A greenhouse experiment was carried out at Agricultural Research Station (ARI), Shen Lasht Chitral in 2016-17. A total of 300 samples were collected from the five different locations namely Drosh, Shen Lasht, Garam Chashma, Ayun and Bony Lasht of district Chitral. The soil samples were placed in trays $\left(27 \mathrm{~cm} \times 21 \mathrm{~cm} \times 4 \mathrm{~cm}=2268 \mathrm{~cm}^{3}\right)$, and the trays were arranged in three repetitions having 100 samples in each repetition. Each repetition contained samples from 5 locations, in each location 4 sites (east, west, north and south each at $100 \mathrm{~m}$ distance from each other) and at each site samples were collected from 5 different depths, making a total of 100 samples in one repetition i.e. $5 \times 4 \times 5=$ 100 and with repetitions making a total of 300 samples in one district. The results identified 31 noxious weeds belong to 17 different plant families in the soil samples of district Chitral.. Out of the 31 different weeds, 23 were broad leaves, 8were grasses and 1was sedge. Moreover, 24 weeds were annuals, while the rest were perennials. A. Among the different locations of Chitral, the highest weed seed bank was recorded in the soil samples of ARS Shen Lasht area.. The lowest seed bank was recorded in the soil samples of Garam Chashma, which was however statistically at par with the rest of the locations studied in Chitral. The major weed seed bank lies in the upper 6-12 cm depth of the soil. Out of the total 31 weeds recorded in soil samples of Chitral, the top 10 weeds in terms of the relative weed densities, relative weed frequencies and importance value indices were Convolvulus arvensis, Rumex crispus, Poa annua, Galium aparine, Avena fatua, Trianthema portulacastrum, Silybum marianum, Sorghum halepense, Euphorbia helioscopia, and Lolium tenulentum species. The Importance Value Indices for these weeds were 14.01, 13.96, $13.07,11.83,11.57,11.12,10.35,10.09,10.02$, and 9.99, respectively. Moreover, these IVIs indicate that out of the top most 10 problematic weeds eight weeds are broad leaved and two are grassy weeds. Therefore, for planning of the weed control measures it must be kept that broad leaf weed problems are higher
\end{abstract}

\section{Keywords:}

Citation: Luqman; Z. Hussain; T. Bakht, Miftah-Ud-Din; H. Khan, M. R. Khan, Ata Ullah, F.A. Shah, I. Khan and A. M. K. Dawar. 2021. Soil Weed Seed Bank Status In The Agroecological Condition Of Chitral, Pakistan. Pak. J. Weed Sci. Res., 27 (3):253-262.

\footnotetext{
${ }^{1}$ Directorate of Agriculture Research (Merged Areas), Agricultural Research Institute (Tarnab) Peshawar, Pakistan; 2 Department of Weed Science and Botany, The University of Agriculture Peshawar, 25130-Peshawar, Pakistan. 3 Department of Environmental Sciences, SBB University Sheringal, Dir Upper

*Corresponding author's email: luqmanweedscientist@aup.edu.pk
} 


\section{Introduction}

The natural storage of plants seeds in the soil of most ecosystems is technically called the seed bank in which some seeds can germinate and some cannot, termed as dormant seeds (Forcella et al., 2004; Smith et al., 2009). So, it is actually the reservoir of living seeds of weeds available either on the topsoil surface or spread inside the vertical soil profile. Both the newly shed weed seeds and the older seeds lying within the soil persistently from past several years (Hassan et al., 2003). All the weeds infesting a particular area give rise to the diverse weed seed bank. The soils of cultivated areas contain millions of weed seeds in a small area which adversely affect the weed seeds dynamics and the strategies required for integrated weed management programs (Espeland et al., 2010; Chauhan and Johnson, 2010). For example, Joshi (1991) reported that the parthenium density in India was around 2000 seeds $\mathrm{m}^{-2}$ in an abandoned field; while according to Navie et al.(2004), the seed bank of parthenium in Australia was in the range of 3,282 5,094 seeds (at Clermont site) and 20,599 - 44,639 seeds $\mathrm{m}^{-2}$ (Moolayember Creeksite).

The soil is the seed bank because the weed seeds deposition and withdrawal take place together, and especially when the seeds in the soil are viable. The seeds production and then their dispersal constitute the seed reservoir in agricultural production systems, which is collectively called the seed deposition (Caroca et al., 2011; De-Cauwer et al., 2010). The viable seeds from the plants or from other areas enter the soil and make seed bank. Cavers (1983) reported that the man-managed storage life of seeds is very much shorter than the natural longevity of the seeds lying in the soil. The land history affects both the weed seed composition and density in a soil. For instance, the seed banks of grassland mostly have seeds that are associated with the non-cropped lands; while the seed banks of the croplands comprise weed seeds from the cultivated agricultural fields (Buhler, 1999). On the other hand, the seeds are lost from the soil seed bank by (1) predation i.e. the process of eating and digestion by different living things like rodents, insects and microbes etc., ( 2 ) by senescence and decay i.e. the seeds are died, and (3) by germination (Khan et al., 2012).

Menalled (2008) is of the view that the seed bank size and composition are a repercussion of the weed management systems applied in the field in past and present and which also determine the weed populations in future. Therefore, it is necessary to diminish the current contribution to the soil (weed seed bank) for planning of weed management in the future. Weed seeds can enter a field by wind, water, animals, and even humans. Humans infest the field with weeds through cultivation and harvesting etc. The question that how far the weed seeds can travel is dependent on the weed species and their dispersal process (Forcella et al., 2004; Grundy, 2003). In a field study, Clements et al. (1996) incorporated the seeds of Avena fatua into the soil of a wheat-fallow field up to the top four inches and observed that about $80 \%$ of those seeds were died in the next winter season. This shows that seed bank can naturally be reduced through seed death called senescence. Similarly, Harbuck (2007) mixed Avena fatua seeds in the top four inches of soil of a wheatfallow field, collected soil samples in spring and fall of the two experimental years, extracted the wild oat seeds from the soil samples, and classified those seeds as the dormant and germinable ones.

The alteration in tillage system and crop rotation can change the weed seed $\mathrm{s}$ composition and density, because the weed seed banks of arable land are dynamic, reflecting the history of cropping in the land, current management strategies, and the environment of the area (Thorne et al., 2007). The 
reproductive output of plants is significantly affected by the domestic animals through direct eating of the aboveground parts of plants; which also impact the fertility and structure of the upper soil, and the integrity of biological crusts is affected through trampling by the grazing animals (Bertiller and Ares, 2011).The seed predation of weeds is another mechanism that is greater in notill systems than in the organic and conventional cropping systems (Menalled, 2008). The chemical mechanism of suppression of weed seeds in the seed bank is due to allelopathy, the process of inhibitory effect of a plant species or a microbe on another living thing through the release of chemicals from the donor species into the environment (Kobayashi, 2004). Hoagland et al. (2008) mentioned the involvement of microbial mechanism in the weed suppression process. Further, the $\mathrm{pH}, \mathrm{C}: \mathrm{N}$ ratio, and microorganisms certainly influence the weed seed germination and longevity inside the soil seedbank (Baskin and Baskin, 2001; Pakeman et al., 2012; Davis et al., 2006). Beckie et al. (2005) reported 35\% expansion in size of a weed patch when they combined the standard weed management practices with other efforts of preventing the weed seed production. During the same period, they also reported $330 \%$ expansion in size of a weed patch when they applied only the standard weed management practices.

District Chitral is an elevated or higher altitude area where mostly the flora that love temperate environments will thrive. Moreover, the hilly areas have very diverse flora which need to be explored and documented properly. Similarly, the depth of soils also has great impact on the diversity and density of the weed seeds infesting the agricultural fields. The upper six inches of the undisturbed soils have the most dense seed bank as compared to the lower profiles because of the continuous seed fall and no soil disturbance. However, in agricultural fields where soil is frequently tilled and pulverized have seed banks very deeper in the soil. Keeping in view the weeds flora, weed seeds composition and densities a study was designed to explore the weed seed banks of the various ecological zones especially the Chitral district of Khyber Pakhtunkhwa.

\section{Materials and Methods}

Chitral is a representative for the higher altitudes and northern areas of the province. Five different locations were selected at Chitral district for the experimentations. The four locations were located in the Eastern, Western, Northern and Southern parts of the target district/region. All the locations were at a distance of at least $10 \mathrm{~km}$ from each other to achieve reliable and robust results. The steps taken for the site selection process were (1) selecting sampling site (permanent plot), (2) surveying and marking corners of plots, (3) creating manageable grids within plots, (4) mapping and identifying spots within sampling plots. Five sites were selected in each of the four selected study locations. As done previously in case of the locations selection, here the four sites were named as eastern, western, northern, and southern whereas the fifth side inside the study locations was chosen in the centre of the rest of the four sites. All the four sites were at a distance of at least $100 \mathrm{~m}$ from the central one.

A quadrate of size $33 \mathrm{~cm} \times 33 \mathrm{~cm}$ was thrown randomly, the soil surface under the quadrate sides was lined, and the soil surface covered under the quadrate lines was dug out with the necessary tools especially the Auger. A total of 5 soil samples were collected from the same spot where the quadrate is thrown i.e. $6,12,18,24$, and $30 \mathrm{~cm}$ depths. The soil up to the $6 \mathrm{~cm}$ depth was collected in a plastic bag and tagged. Then the next $6 \mathrm{~cm}$ soil profile was dug out and the sample was collected in another separate bag and tagged, and so on. The same procedure was followed for all the depths; thus making soil collection from a total of one foot depth. The volume of all the soil samples remained the same i.e. 
$33 \mathrm{~cm}$ long, $33 \mathrm{~cm}$ wide and $6 \mathrm{~cm}$ deep. Similarly the quadrates were thrown randomly three times to make a total of three repetitions and the same above given procedure was followed. This completed one site in the first location, making a total of 15 samples i.e. 5 (depths) $\times 3$ (quadrates) $=15$. As there were four more sites in the first location of the district. The procedure in the previous paragraph was followed for the rest of these sites in the first location. With this we completed the first location of the Chitral district, making a total of 75 samples i.e. 5 (depths) $\times 3$ (quadrates) $x$ 5 (sites) $=75$. In short, the required steps were, (1) collecting soil samples from plot, (2) at each sampling point, using the bulb planter remove the litter layer, if any, measuring it for depth (Retain the litter sample), (3) using the bulb planter to collect the mineral soil to a depth of 6,12 , 18,24 , and $30 \mathrm{~cm}$ from each sampling point, and (4) combining soil and litter samples and bringing to lab for germination.

The 300 soil samples collected were placed in trays of medium sizes i.e. $27 \mathrm{~cm} \times 21 \mathrm{~cm} \times 4 \mathrm{~cm}=2268 \mathrm{~cm}^{3}$. The trays were arranged in three repetitions having 100 samples in each repetition. Each repetition of 100 samples contained samples from 5 depths, of 5 sites, from 4 locations i.e. $5 \times 5 \times 4=100$ in district Chitral. The trays were uniformly watered for the existing seeds germination. The data were collected after every two days for the first 5 weeks regarding the number of seeds germinated, also whether the seeds germinated were of broadleaf weeds, grasses and/or sedges. After the first 5 weeks, the data were collected on weekly basis for the next 5 weeks i.e. up to the completion of 10 weeks of the experimentation. Then data were collected on fortnightly basis for the next 10 weeks, thus at the completion of 20 weeks of the experimentation, the data collection were stopped for the current season.

\section{Statistical analyses}

The data regarding the identification and enlisting did not need to be analysed. Similarly, the data for importance value indices did not require statistical analysis. However, the data for the weed seed bank have been analyzed and using statistical softwares Statistix 8.1. The design used was completely randomized design (CRD) for all the pot experiments. The ANOVA tables were generated for each factor involved and the significant means were separated using the LSD test (Steel and Torrie, 1980).

\section{Results and Discussion Weed flora}

Table- 1 indicates a total of 31 noxious weeds that are severely infesting the maize and wheat growing areas of Chitral region. These weeds were visually observed during the official trips to the target areas for soil samples collection and then the almost the same flora was recorded in the germination process of the weed seeds from the soil samples put in trays of known sizes at green houses one each at ARS Chitral. The areas studied in Chitral region were the ARC Shenlast, Drosh, Boni, Ayun and Gharam Chashma areas. All these locations were at least 5$10 \mathrm{~km}$ or even at more distance from each other to make the data more reliable. Out of the 31 different weeds, 23 were broad leaves, eight were grasses and one was a sedge. The one sedge also is stronger than many of the grasses and broadleaves together in terms of infestation and yield losses. Moreover, among the 31 weeds, 24 were annuals while the rest were perennials; no biennial weed was recorded in the studied areas of Chitral. It is noteworthy that all the 31 weeds belonged to 17 different families of plant kingdom. The following is the detailed inventory of the reported weeds in alphabetical order of their botanical/technical names. Melilotus indicus is a leguminous weed in the list. 
Table-1. Weed flora in the seed bank studies at Chitral district, Pakistan during 2016-17.

\begin{tabular}{|c|c|c|c|c|}
\hline S. No. & Botanical name & Family & Life cycle & Morphology \\
\hline 1. & Achyranthes aspera & Amaranthaceae & Annual & Broad leaf \\
\hline 2. & Anagallis arvensis & Primulaceae & Annual & Broad leaf \\
\hline 3. & Avena fatua & Poaceae & Annual & Grass \\
\hline 4. & Cannabis sativa & Cannabaceae & Annual & Broad leaf \\
\hline 5. & Capsella bursa-pastoris & Brassicaceae & Annual & Broad leaf \\
\hline 6. & Cenchrus longispinus & Poaceae & Annual & Grass \\
\hline 7. & Cirsium arvense & Asteraceae & Perennial & Broadleaf \\
\hline 8. & Convolvulus arvensis & Convolvulaceae & Annual & Broad leaf \\
\hline 9. & Coronopus didymus & Brassicaceae & Annual & Broad leaf \\
\hline 10. & Digitaria sanguinalis & Poaceae & Perennial & Grass \\
\hline 11. & Eclipta alba & Asteracear & Annual & Broadleaf \\
\hline 12. & Euphorbia helioscopia & Euphorbiaceae & Annual & Broad leaf \\
\hline 13. & Fumaria indica & Fuariaceae & Annual & Broad leaf \\
\hline 14. & Galium aparine & Rubiacae & Annual & Broad leaf \\
\hline 15. & Imperata cylindrical & Poaceae & Perennial & Grass \\
\hline 16. & Lolium tenulentum & Poaceae & Annual & Grass \\
\hline 17. & Melilotus indicus & Papilionaceae & Annual & Broad leaf \\
\hline 18. & Oxalis corniculata & Oxalidaceae & Perennial & Broadleaf \\
\hline 19. & Peganum harmala & Zygophyllaceae & Annual & Broad leaf \\
\hline 20. & Phalaris minor & Poaceae & Annual & Grass \\
\hline 21. & Plantago lanceolata & Plantiginaceae & Perennial & Broad leaf \\
\hline 22. & Poa annua & Poaceae & Annual & Grassy \\
\hline 23. & Polygonum aviculare & Polygonaceae & Annual & Broadleaf \\
\hline 24. & Rumex crispus & Polygonaceae & Perennial & Broadleaf \\
\hline 25. & Silybum marianum & Asteraceae & Annual & Broadleaf \\
\hline 26. & Sisymbrium irio & Brassicaceae & Annual & Broad leaf \\
\hline 27. & Sorghum halepense & Poaceae & Annual & Grassy \\
\hline 28. & Stellaria media & Caryophyllaceae & Annual & Broad leaf \\
\hline 29. & Taraxacum officinale & Asteraceae & Perennial & Broad leaf \\
\hline 30. & Trianthema portulacastrum & Aizoaceae & Annual & Broad leaf \\
\hline 31. & Withania coagulans & Solanaceae & Annual & Broad leaf \\
\hline
\end{tabular}

\section{Weed seed banks}

Statistical analysis of the data (Table-2) showed that the different locations, soil depths and their interactions had a significant effect on the weed seed bank density $\mathrm{m}^{-2}$ in the field conditions of the wheat and maize growing areas of District Chitral. Among the different locations of Chitral, the highest weed seed bank $\left(245.15 \mathrm{~m}^{-2}\right)$ was recorded in the soil samples of ARS Shen Lasht area. This showed that the said area has the highest no. and types of weeds. This higher weed seed bank in the area could be a result of many factors such as the type of weed control measures, the type of crops grown annually in the area, the type of herbicides used for weed control etc. Similarly, weed seed banks have always been higher in areas with mild winters (Ji-Guang and Qun-Xing, 2006)as the Shen lasht area is having milder winters as compared to the other areas in the Chitral district. While, the lowest seed bank was recorded in the soil samples of Garam Chashma, which was however statistically at par with the rest of the locations. Moreover, the seed bank was largest in the depth of $6 \mathrm{~cm}(346.56$ $\left.\mathrm{m}^{-2}\right)$, followed by that of $12 \mathrm{~cm}(278.66$ $\left.\mathrm{m}^{-2}\right)$. The smallest seed bank was at the depth of $30 \mathrm{~cm}\left(70.54 \mathrm{~m}^{-2}\right)$ followed by the depth of 24 and $18 \mathrm{~cm}$ (124.35 and $205.47 \mathrm{~m}^{-2}$, respectively. Therefore, it is 
evident that the major weed seed bank lies in the upper $6 \mathrm{~cm}$ depth of the soil. Because of the shallow tillage, the weed seeds do not go deeper in the soil due to which the seed bank remains lower. By the frequent use of organic matter and irrigation, most of the weed seeds remained on the upper most or slight beneath the upper fertile soil layer that increased the seed bank of the upper soil portion i.e. from 6-12 cm depth. In a similar study, Carter and Ivany (2005)also found highest weed seed bank at the same lower depths of the soil. The larger weed seed banks are also due to the ignorance of the responsible organizations or people regarding weeds infestation. Rao (2000) is of the view that one year seeding results in seven years weeding. The seed bank below $18 \mathrm{~cm}$ is lower because of the higher withdrawal rate through senescence and microbial effect, and also due to lower seed deposition at $20 \mathrm{~cm}$ depth. Reza and Mahdi (2005) reported that seed banks are always higher where inputs are higher and vice versa. Weeds produce very large number of seeds per plant and if not managed in time can create an aggravated situation in agricultural areas. The interaction effect of different locations and soil depths was also significant. In case of the interaction, the largest weed seed bank (396.80 $\mathrm{m}^{-2}$ ) was recorded at ARS Sheen lasht at the depth of upper $6 \mathrm{~cm}$ of the soil profile where as there were only $\left(348.33 \mathrm{~m}^{-2}\right)$ weed seeds $\mathrm{m}^{-2}$ below the $12 \mathrm{~cm}$ depth of soil upto $30 \mathrm{~cm}$ in the Garam Chashma area of Chitral. This apparently indicates that Garam Chashma is not rich in flora and the seed bank becomes very low at the $18 \mathrm{~cm}$ depth over there.

Table-2. Weed seed banks (no. of weed seeds $\mathrm{m}^{-2}$ ) in wheat and maize growing areas at various five locations and five different soil depths in Chitral (Higher altitude), Pakistan during 2016-17.

\begin{tabular}{|c|c|c|c|c|c|c|}
\hline \multirow[t]{2}{*}{ Sites } & \multicolumn{5}{|c|}{ Depths (cm) } & \multirow{2}{*}{$\begin{array}{l}\text { Sites } \\
\text { Means }\end{array}$} \\
\hline & 6 & 12 & 18 & 24 & 30 & \\
\hline $\begin{array}{l}\text { ARS Shen } \\
\text { Lasht }\end{array}$ & $396.80 \mathrm{a}$ & $330.67 \mathrm{abc}$ & $\begin{array}{l}273.38 \\
\text { bcde }\end{array}$ & $149.93 \mathrm{hij}$ & $74.95 \mathrm{Im}$ & $245.15 \mathrm{a}$ \\
\hline Drosh & $313.08 \mathrm{bcd}$ & $\begin{array}{l}277.78 \\
\text { bcd }\end{array}$ & $207.45 \mathrm{efg}$ & $\begin{array}{l}158.72 \\
\text { ghi }\end{array}$ & $83.75 \mathrm{klm}$ & $208.12 a b$ \\
\hline BoniLasht & $335.10 \mathrm{abc}$ & $286.60 \mathrm{bcd}$ & $198.40 \mathrm{fgh}$ & $110.22 \mathrm{ijk}$ & $\begin{array}{l}88.17 \\
\mathrm{jklm}\end{array}$ & $203.70 b$ \\
\hline Ayun & $348.33 a b$ & 264.55 cde & $180.75 \mathrm{ghi}$ & $101.42 \mathrm{ijk}$ & $61.70 \mathrm{~m}$ & $191.35 \mathrm{~b}$ \\
\hline $\begin{array}{l}\text { Garam } \\
\text { Chashma }\end{array}$ & $339.50 \mathrm{abc}$ & 233.70 def & $167.55 \mathrm{ghi}$ & $101.42 \mathrm{ijk}$ & $44.10 \mathrm{~m}$ & $177.26 \mathrm{~b}$ \\
\hline $\begin{array}{l}\text { Depths } \\
\text { Means }\end{array}$ & $346.56 a$ & $278.66 b$ & $205.47 c$ & $124.35 \mathrm{~d}$ & $70.54 \mathrm{~d}$ & \\
\hline
\end{tabular}

\section{Weed Densities, Frequencies and}

\section{Importance Value Indices}

The individual weed densities, relative densities, frequencies, relative frequencies and importance value indices of all the weeds that germinated from the trays bearing the soil samples of different ecological locations and varying soil depths are mentioned in Table-3. It is pertinent to mention that the primary data obtained from the trays were converted to per square meter for having data in standard units. For the data on frequencies, a total of 100 trays were selected so that the percentages could be easily calculated. The following Table-3.1 is indicating the relative densities and frequencies for the different ecological locations and for the varying soil depths. The description of weeds includes the weed densities and frequencies of the 
individual weeds germinated from the respective trays, and their relative weed densities. Our findings are in conformity with Mirsky et al. (2010) that weed seed bank is dependent on the soil disturbance i.e. the deeper the disturbance, the deeper will be the seed bank into the soil. Douglas et al. (2001) found concentrated weed seed bank in the upper $10 \mathrm{~cm}$ of the soil profile due to different cultural practices, the time and application of weed control methods. In addition to the relative weed densities and weed frequencies, the importance value indices of the various weeds germinated from the soil samples of different locations and different depths of district Chitral are also calculated. The botanical names of the species are enlisted in alphabetical order as mentioned above in the tables of weed flora of the respective regions. Out of the total 31 weeds recorded in soil samples of Chitral, the top 10 weeds in terms of the relative weed densities (RWD), relative weed frequencies (RWF) and importance value indices (IVI) were $C$. arvensis, $R$. crispus, $P$. annua, G. aparine, A. fatua, $T$. portulacastrum, S. marianum, $S$. halepense, E. helioscopia, and L. tenulentum. The IVIs for these weeds were 14.01, 13.96, 13.07, 11.83, 11.57, $11.12,10.35,10.09,10.02$, and 9.99, respectively. These IVIs indicate that out of the top most 10 problematic weeds eight weeds are broad leaved and two are grassy weeds. Therefore, for planning of the weed control measures it must be kept that broad leaf weed problems are higher as compared to the grassy weeds. For details of IVIs, Table 3.1 may be observed.

Table-3. Individual weed densities, frequencies and importance value indices of different weeds in district Chitral, Khyber Pakhtunkhwa, Pakistan during 2016-17.

\begin{tabular}{|l|c|c|c|c|c|c|}
\hline Weeds & WD & RWD & WF & RWF & IVI & $\begin{array}{c}\text { Order of } \\
\text { Severity }\end{array}$ \\
\hline Achyranthes aspera & 9 & 0.88 & 3 & 0.50 & 1.38 & 30 \\
\hline Anagallis arvensis & 23 & 2.24 & 11 & 1.84 & 4.08 & 20 \\
\hline Avena fatua & 62 & 6.05 & 33 & 5.52 & 11.57 & 5 \\
\hline Cannabis sativa & 29 & 2.83 & 13 & 2.17 & 5.00 & 16 \\
\hline Capsella bursa-pastoris & 14 & 1.37 & 7 & 1.17 & 2.54 & 24 \\
\hline Cenchrus longispinus & 5 & 0.49 & 3 & 0.50 & 0.99 & 31 \\
\hline Cirsium arvense & 49 & 4.78 & 23 & 3.85 & 8.63 & 11 \\
\hline Convolvulus arvensis & 75 & 7.32 & 40 & 6.69 & 14.01 & 1 \\
\hline Coronopus didymus & 40 & 3.90 & 24 & 4.01 & 7.92 & 13 \\
\hline Digitaria sanguinalis & 42 & 4.10 & 25 & 4.18 & 8.28 & 12 \\
\hline Eclipta alba & 22 & 2.15 & 13 & 2.17 & 4.32 & 18 \\
\hline Euphorbia helioscopia & 53 & 5.17 & 29 & 4.85 & 10.02 & 9 \\
\hline Fumaria indica & 22 & 2.15 & 12 & 2.01 & 4.15 & 19 \\
\hline Galium aparine & 63 & 6.15 & 34 & 5.69 & 11.83 & 4 \\
\hline Imperata cylindrical & 23 & 2.24 & 17 & 2.84 & 5.09 & 15 \\
\hline Lolium tenulentum & 51 & 4.98 & 30 & 5.02 & 9.99 & 10 \\
\hline Melilotus indicus & 12 & 1.17 & 7 & 1.17 & 2.34 & 27 \\
\hline Oxalis corniculate & 17 & 1.66 & 8 & 1.34 & 3.00 & 22 \\
\hline Peganum harmala & 11 & 1.07 & 6 & 1.00 & 2.08 & 29 \\
\hline Phalaris minor & 31 & 3.02 & 20 & 3.34 & 6.37 & 14 \\
\hline
\end{tabular}




\begin{tabular}{|l|c|c|c|c|c|c|}
\cline { 1 - 3 } Plantago lanceolata & 15 & 1.46 & 11 & 1.84 & 3.30 & 21 \\
\hline Poa annua & 62 & 6.05 & 42 & 7.02 & 13.07 & 3 \\
\hline Polygonum aviculare & 15 & 1.46 & 9 & 1.51 & 2.97 & 23 \\
\hline Rumex crispus & 66 & 6.44 & 45 & 7.53 & 13.96 & 2 \\
\hline Silybum marianum & 53 & 5.17 & 31 & 5.18 & 10.35 & 7 \\
\hline Sisymbrium irio & 11 & 1.07 & 8 & 1.34 & 2.41 & 26 \\
\hline Sorghum halepense & 52 & 5.07 & 30 & 5.02 & 10.09 & 8 \\
\hline Stellaria media & 12 & 1.17 & 8 & 1.34 & 2.51 & 25 \\
\hline Taraxacum officinale & 22 & 2.15 & 15 & 2.51 & 4.65 & 17 \\
\hline Trianthema portulacastrum & 54 & 5.27 & 35 & 5.85 & 11.12 & 6 \\
\hline Withania coagulans & 10 & 0.98 & 7 & 1.17 & 2.15 & 28 \\
\hline Total & 1025 & & 598 & & & \\
\hline
\end{tabular}

\section{Conclusions and Recommendations}

The weed seed banks (composition and densities) in all the ecological regions of Chitral of Khyber Pakhtunkhwa are rich in weed flora. The weeds in all the ecological regions studied are very diverse and their diversity and density differ from region to region. In Chitral, 31different weed species have been recorded respectively. The leguminous weeds have also been identified that help improve the soil fertility. These weeds included Alhaji maurorum, Lathyrus aphaca, Medicago denticulata, Melilotus indica, and Vicia sativa. In light of the importance value indices calculated, the severity wise chronological orders of the weeds have been generated for all the studied regions. Ecological conditions and human interference has got a big role in the alteration of the seed banks. The areas where the seed bank is higher in the upper 6 to $12 \mathrm{~cm}$ soil depths should be left fallow for a season after plowing without any crop seed. 


\section{Literature Cited}

Baskin, C.C. and J.M. Baskin. 2001. Seeds: Ecology, Biogeography and Evolution of Dormancy and Germination. Academic Press, San Diego, CA.

Beckie, H., L.M. Hall and B. Schuba. 2005. Patch management of herbicideresistant wild oat (Avenafatua). Weed Technol. 19: 697-705.

Bertiller, M.B. and J.O. Ares. 2011. Does sheep selectivity along grazing paths negatively affect biological crusts and soil seed banks in arid shrublands? A case study in the Patagonian Monte, Argentina. J. Environ. Manage. 92: 2091-2096.

Buhler, D.D. 1999. Weed population responses to weed control practices. I. Seed bank, weed populations, and crop yields. Weed Sci. 47:416-422.

Caroca, R.P., P.S. Candia, and E.A. Hinojosa. 2011. Characterization of the weed seed bank in zero and conventional tillage in central Chile.Chil. J. Agr. Res. 2011, 71(1): 140-147.

Carter, M.R. and J.A. Ivany. 2005. Weed seed bank composition under three long-term tillage regimes on a fine sandy loam in Atlantic Canada. Soil Till. Res. 90(1): 29-38.

Cavers, P.B. 1983.Seed demography. Can. J. Bot., 61:3678-3690.

Chauhan, B.S. and D.E. Johnson. 2010. The Role of Seed Ecology in Improving Weed Management Strategies in the Tropics. Adv. Agron. 105: 221-262.

Clements, D.R., D.L. Benoit and C.J. Swanton. 1996. Tillage effects on weed seed return and seed bank composition. Weed Sci. 44: 314-322.

Davis, A.S., K.I. Anderson, S.G. Hallett and K.A. Renner. 2006. Weed seed mortality in soils with contrasting agricultural management histories. Weed Sci. 54: 291-297.

De-Cauwer, B., K. Van den Berge, M. Cougnon, R. Bulcke, D. Reheul. 2010. Weed seed bank response to 12 years of different fertilization systems.
Common Agric Appl Biol. Sci. 75(2):61-72.

Douglas, D.B., A.K. Kohler and R.L. Thompson. 2001. Weed seed bank dynamics during a five-year crop rotation. Weed Technol. 15:170-176.

Espeland, E.K., B.L. Perkins, and E.A. Leger. 2010. Comparison of seed bank estimation techniques using six weed species in two soil types. Rangeland Ecol. Manage., 63:243247.

Forcella, F.T., Y. Webster, and J. Cardina. 2004. Protocolospara la determinacin de bancos de semillas de malezasen los agrosistemas. Captulo 1. p. 3-22. In:R. Labrada, (ed.) Manejo de malezasparapaaesendesarrollo.

Estudio FAO Produccin y Proteccin Vegetal-120. Addendum I. FAO, Roma, Italia.

Grundy, A.C. 2003. Predicting weed emergence: a review of approaches and future challenges. Weed Res. 43(1): 1-11.

Harbuck, K.Z. 2007. Weed seed bank dynamics and composition of Northern Great Plains cropping systems. Montana State University MS thesis.

Hassan, G., H. Khan, K.B. Marwat and M.A. Khan. 2003. Studies on weed seed dynamics in soil seed bank of rice-based cropping system of Pakistan. Pak. J. Weed Sci. Res. 9(34): 259-264.

Hoagland, L., L. Carpenter-Boggs, J.P. Reganold and M. Mazzola. 2008. Role of native soil biology in Brassicaceous seed meal-induced weed suppression. Soil Biol. Biochem. 40: 1689-1697.

Ji-guang and Z. Qun-xing. 2006. A preliminary discussion on the turfweed sustainable management from the soil weed seed bank. J. Xinyang Agric. Coll. 41: 234-239.

Joshi, S. 1991. Biocontrol of Parthenium hysterophorus L. Crop Protection 10: 429-431.

Khan, A.M, Z. Hussain, I. Khan, R. Khan, M. Waqas, M. Haroon, Z. Ali and I.A. Khan. 2012. Studies on weed seed bank of new developmental farm, KPK Agricultural University Peshawar, 
Pakistan. Pak. J. Weed Sci. Res. 18(2): 183-189.

Kobayashi, K. 2004. Factors affecting phytotoxic activity of allelochemicals in soil. Weed Biol. Manage. 4: 1-7.

Menalled, F. 2008. Weed Seedbank Dynamics \& Integrated Management of Agricultural Weeds. MontGuide. MT200808AG New 7.

Mirsky, B., E.R. Gallandt, D.A. Mortensen, W.S. Curran and D.L. Shumway. 2010. Reducing the germinable weed seedbank with soil disturbance and cover crops. Weed Res. 50: 341-352.

Navie, S.C., F.D. Panetta, R.E. McFadyen and S.W. Adkins. 2004. Germinable soil seed banks of central Queensland rangelands invaded by the exotic weed Parthenium hysterophorus L. Weed Biol. Manage. 4: 154-167.

Pakeman, R.J., J.L. Small and L. Torvell. 2012. Edaphic factors influence the longevity of seeds in the soil. Plant Ecol. 213: 57-65.
Rao, V.S. 2000. Harmful effects caused by weeds. Principles of Weed Science.Oxford and IBH publishing Co. Pvt. Ltd. New Delhi and Calcutta, pp. 1.

Reza, K.A., and N.M. Mahdi. 2005. Effects of different input levels on weed seed bank in wheat fields of mashhad. Iran. J. Field Crops Res. 3(1): 89-102.

Smith, R.G., R. Jabbour, A.G. Hulting, M.E. Barbercheck, and D.A. Mortensen. 2009. Effects of initial seed-bank density on weed seedling emergence during the transition to an organic feed-grain crop rotation. Weed Sci. 57:533-540.

Thorne, M.E., F.L. Young and J.P. Yenish. 2007. Cropping systems alter weed seed banks in Pacific Northwest semiarid wheat region. Crop Protec. 26: 1121-1134. 